\title{
Activation of Overexpressed Receptors for Insulin and Epidermal Growth Factor Interferes in Mitogenic Signaling without Affecting the Activation of p21ras
}

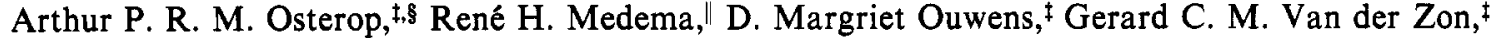 \\ Wim Möller, ${ }^{\ddagger}$ and J. Antonie Maassen ${ }^{*} \ddagger$ \\ Laboratory of Protein Synthesis and Hormone Regulation, Sylvius Laboratory, Wassenaarseweg 72, 2333 AL Leiden, \\ The Netherlands, and Laboratory for Physiological Chemistry, Utrecht University, Vondellaan $24 A$,
} 3521 GG Utrecht, The Netherlands

Received September 22, 1993; Revised Manuscript Received March 29, $1994^{\circ}$

\begin{abstract}
Activated receptors with a tyrosine kinase activity induce a variety of responses like changes in the differentiation and mitogenic status of cells. These responses are mediated in part by $\mathrm{p} 21$ ras. Some of these activated receptors induce in certain cell types a pronounced, but transient, increase in Ras.GTP. We have stimulated cells with insulin, epidermal growth factor (EGF), and fetal calf serum (FCS), and the mitogenic response, as reflected by stimulation of $\left[{ }^{3} \mathrm{H}\right]$ thymidine incorporation, was compared with the magnitude of the transient increase in Ras.GTP levels. Cell lines were used that expressed both physiological and elevated numbers of $\mathrm{p} 21$ ras and receptors for insulin and EGF, respectively. In all the examined cell lines $9 \%$ FCS did not induce a marked increase in Ras-GTP despite its high mitogenic potency. Pronounced increases in Ras.GTP levels were observed in insulin-stimulated CHO cells which overexpress insulin receptors whereas in the parental CHO cells only a small increase is seen. Insulin $(1 \mu \mathrm{M})$ and FCS (9\%) stimulate $\left[{ }^{3} \mathrm{H}\right]$ thymidine incorporation in parental $\mathrm{CHO}$ cells to a similar high level whereas in insulin receptor overexpressing $\mathrm{CHO}$ cells the maximum of insulin-stimulated $\left[{ }^{3} \mathrm{H}\right]$ thymidine incorporation is only $55 \%$ of the level reached by $9 \%$ FCS. In those cells the maximum is already reached at low (1 nM) insulin concentrations. Remarkably, at higher insulin concentrations stimulation of $\left[{ }^{3} \mathrm{H}\right]$ thymidine incorporation starts to decrease strongly despite the fact that the magnitude of the transient increase in Ras.GTP and subsequent MAPkinase activation increases. Similarly, when EGF receptors are overexpressed in Rat-1 cells, the mitogenic response is also decreased at higher EGF concentrations. In cells overexpressing insulin receptors and having normal EGF receptor numbers, EGF-induced $\left[{ }^{3} \mathrm{H}\right]$ thymidine incorporation is abolished by full activation of the overexpressed insulin receptors. Vice versa, in cells overexpressing EGF receptors and having physiological numbers of insulin receptors, $1 \mu \mathrm{M}$ insulin induces a maximum in $\left[{ }^{3} \mathrm{H}\right]$ thymidine incorporation, and this response is completely blocked by costimulation with $0.1 \mu \mathrm{M}$ EGF. Also, the serum-induced $\left[{ }^{3} \mathrm{H}\right]$ thymidine incorporation is strongly suppressed by full stimulation of the overexpressed receptors. The results indicate that $\left[{ }^{3} \mathrm{H}\right]$ thymidine incorporation in cells does not correlate with the magnitude of the early response of Ras.GTP formation. In addition, high numbers of autophosphorylated receptors inhibit the mitogenic response, also when it is elicited by another growth factor.
\end{abstract}

The ras protooncogenes encode small guanine nucleotide binding proteins with molecular masses of approximately $21 \mathrm{kDa}$ (Barbacid, 1987). P21 ras is active when complexed to GTP. It has a slow intrinsic GTPase activity that converts Ras.GTP into inactive Ras-GDP. This activity is enhanced by cellular proteins like p120-GAP ${ }^{1}$ and NF1-GAP (McCormick, 1992). Activation of p21ras requires exchange of bound GDP for GTP (Randazzo et al., 1992). A variety of proteins, regulating this exchange, have been identified (West et al., 1990; Downward et al., 1990b; Wolfman \& Macara,

* Address correspondence to this author at the Laboratory of Protein Synthesis and Hormone Regulation, Sylvius Laboratory, Wassenaarseweg 72, 2333 AL Leiden, The Netherlands. Tel (31) 71 276127, fax (31) 71 276125.

¥ Sylvius Laboratory.

- Present address: COEUR, University Hospital Dijkzigt, Dr. Molewaterplein 40, 3015 GD Rotterdam, The Netherlands.

I Utrecht University.

- Abstract published in Advance ACS Abstracts, May 15, 1994.

1 1Abbreviations: CHO, Chinese hamster ovary; DMEM, Dulbecco's modified Eagle's medium; $\mathrm{EC}_{50}$, half-effective concentration; EGF, epidermal growth factor; FCS, fetal calf serum; GAP, GTPase activating protein; MAPkinase, mitogen-activated protein kinase; NF1, neurofibromatosis-1 gene product; PAGE, polyacrylamide gel electrophoresis; PDGF, platelet-derived growth factor; $\mathrm{PKC}$, protein kinase $\mathrm{C} ; \mathrm{SH} 2 / 3$ domain, sre homology region 2 or 3 domain.
1990; Veda et al., 1991; Egan et al., 1993; Buday \& Downward, 1993).

Several extracellular ligands have been described which induce Ras.GTP formation in cultured cells (Downward et al., 1990a; Satoh et al., 1990a,b; Burgering et al., 1991; Qiu \& Green, 1991; Nakafuku et al., 1992; Izquierdo et al., 1992; Graves et al., 1992). Most of them activate tyrosine kinase receptors. Insulin and EGF stimulation of cells induce a rapid, but transient, increase in Ras-GTP formation, and evidence is emerging that this process is mediated by an increase in the guanine nucleotide exchange rate rather than by inhibition of the GTPase reaction. Protein-protein interactions, mediated by binding of SH2 domains to phosphotyrosine moieties or by binding of SH3 domains to proline-rich domains, transduce many of the signals between these tyrosine kinase receptors and p21ras (McCormick, 1993; Skolnik et al., 1993). It is suggestive that this type of protein-protein interaction is also involved in signaling downstream of $\mathrm{p} 21$ ras since $\mathrm{p} 120-\mathrm{GAP}$, which contains SH2 and SH3 domains, seems to act as an attenuator of Ras.GTP but also as a putative effector molecule (Medema et al., 1992; Duchesne et al., 1993). By using p21rasneutralizing antibodies and dominant inhibitory p21ras mutants, it has become clear that p21 ras is required for the 
Table 1: Properties of Cell Lines Used in This Study ${ }^{a}$

\begin{tabular}{llcl}
\hline & \multicolumn{3}{c}{ cell $^{-1}$} \\
\cline { 2 - 4 } cell lines & EGF receptors & insulin receptors & p21 ras molecules \\
\hline CHO9 & none & 5000 & nd \\
IR800 & none & 1600000 & nd \\
Rat-1 & 11000 & 30000 & 27000 \\
R1HER & $250000^{c}$ & 30000 & 27000 \\
Hras13 & 10000 & 29000 & 2600000 \\
H13IR2000 & 40000 & 750000 & 2600000 \\
A14 & nd & 700000 & nd
\end{tabular}

a Epidermal growth factor and insulin receptor numbers were quantitated by Scatchard analysis of binding data. nd, not determined. ${ }^{b}$ p21 ras numbers are taken from Downward et al. (1988). ${ }^{c}$ EGF receptor number is taken from Moran et al. (1991).

induction of mitogenicity and cellular differentiation by tyrosine kinases (Grand \& Owen, 1991; Smith et al., 1986; Cai et al., 1990; Medema et al., 1991; Kung et al., 1986; Szeberényi et al., 1992). Furthermore, microinjection of Ras.GTP alone induces DNA synthesis, indicating that Ras.GTP is sufficient for induction of DNA synthesis (Stacey \& Kung, 1984; Feramisco et al., 1984).

We have reported previously that EGF receptors induce Ras.GTP formation more efficiently than insulin receptors (Osterop et al., 1993). In this report we describe experiments to examine to what extent the early response of Ras.GTP formation, induced by these two different tyrosine kinase receptors, corresponds to the magnitude of the mitogenic response. We show that Ras.GTP levels induced by insulin, EGF, and fetal calf serum are poor predictors of the magnitude of the mitogenic response. We also show that the presence of large numbers of activated insulin and EGF receptors can abrogate hormone- and serum-induced mitogenicity.

\section{EXPERIMENTAL PROCEDURES}

Materials. All chemicals used were analytical grade. Tissue culture media, sera, and methotrexate were from Gibco. Phosphate-free Dulbecco's modified Eagle's medium (DMEM) and bovine insulin were from Sigma. Epidermal growth factor and the mycoplasma detection kit were from Boehringer Mannheim. The anti-p21 ras monoclonal antibody, Y13-259, was kindly provided by Dr. A. Zantema (this department), and the anti-MAPkinase polyclonal antibody [ERK1 (691)] was from Santa Cruz Biotechnology Inc. [32P]Orthophosphate (carrier free) and $\left[{ }^{3} \mathrm{H}\right]$ thymidine were from Amersham.

Cell Lines. The Hras 13 and R1HER cell lines are derived from Rat-1 cells and overexpress wild-type $221 \mathrm{Hras}$ and the receptor for epidermal growth factor, respectively (Downward et al., 1988; Moran et al., 1991). All cell lines were cultured in DMEM with $9 \%$ fetal calf serum.

Cell lines overexpressing insulin receptors were constructed by transfecting $\mathrm{CHO}$, Hras 13 , and NIH3T3 cells with a plasmid containing the human wild-type insulin receptor cDNA, yielding, respectively, the cell lines IR $800, \mathrm{H} 13$ IR2000, and A14, as described before (Osterop et al., 1992, 1993). The cell lines were maintained in DMEM, $9 \%$ fetal calf serum (dialyzed against phosphate-buffered saline), and $25 \mathrm{nM}$ methotrexate.

Cell lines were regularly tested for the absence of mycoplasma using the mycoplasma enzyme immunoassay kit.

Quantitation of epidermal growth factor and insulin receptor numbers on cells was by Scatchard analysis. The characteristics of the various cell lines are listed in Table 1. During long-term culturing of the cells Western blot analysis was regularly performed to monitor receptor and 221 ras expression levels.
Cell Labeling and Analysis of p21ras-Bound Guanine Nucleotides and Insulin Receptor Autophosphorylation. The amount of guanine nucleotides bound to p21 ras and autophosphorylation of the insulin receptor was quantitated as described before (Osterop et al., 1992). In short, serum-starved cells were labeled with [ ${ }^{32} \mathrm{P}$ ] 0 rthophosphate and stimulated with insulin, EGF, or FCS for $5 \mathrm{~min}$. Cells were lysed in buffer containing $1 \%$ Triton X-114. After temperatureinduced phase separation of the lysates, the detergent phase was used to immunoprecipitate $\mathrm{p} 21$ ras and the aqueous phase was used to immunoprecipitate the insulin receptor.

P21 ras-bound guanine nucleotides were separated by thinlayer chromatography, and the radioactivity in GDP and GTP was quantitated by liquid scintillation chromatography.

Proteins in the anti-insulin receptor immunoprecipitates were analyzed by SDS-PAGE under reducing conditions. Incorporation of ${ }^{32} \mathrm{P}$ into the insulin receptor $\beta$-chain was quantitated by liquid scintillation counting of the corresponding gel slices.

$\left[{ }^{3} \mathrm{H}\right]$ Thymidine Incorporation. The stimulation of the DNA synthesis was quantitated as described previously (Osterop et al., 1992). Serum-starved cells were stimulated with insulin, EGF, or FCS for $16 \mathrm{~h}$. During the last $2 \mathrm{~h}$ $\left[{ }^{3} \mathrm{H}\right]$ thymidine was present in the culture medium. Radioactivity incorporated into DNA was quantitated by liquid scintillation counting and was less than $60 \%$ of added radioactivity.

MAPkinase Phosphorylation. One million IR 800 and A14 cells, respectively, were grown to confluency and were serumstarved for $24 \mathrm{~h}$. Insulin was added, and incubation was performed for $5 \mathrm{~min}$. Cells were washed with ice-cold phosphate-buffered saline and lysed in $300 \mu \mathrm{L}$ of SDS sample buffer. Twenty-five microliters was used for Western blot analysis using polyclonal anti-MAPkinase antibody $(1: 2000)$. Alkaline phosphatase-conjugated anti-IgG antibody was used for visualization.

\section{RESULTS}

Insulin- and EGF-Induced $\left[{ }^{3} \mathrm{H}\right]$ Thymidine Incorporation into DNA. The cell lines used are listed in Table 1. One panel of cells (Figure 1A) consists of $\mathrm{CHO} 9$ cells and a $\mathrm{CHO}$ derived cell line overexpressing the human insulin receptor (IR800). The second panel (Figure 1B) consists of Rat-1 cells, Rat-1-derived cells overexpressing p 21 ras (Hras 13), Rat1-derived cells overexpressing both $\mathrm{p} 21$ ras and the insulin receptor (H13IR2000), and Rat-1-derived cells overexpressing the EGF receptor alone (R1HER).

The serum-starved cells were stimulated with different concentrations of insulin or EGF, and $\left[{ }^{3} \mathrm{H}\right]$ thymidine incorporation into DNA was quantitated. These values are expressed in Figure 1 as the percentage of $\left[{ }^{3} \mathrm{H}\right]$ thymidine incorporation induced by $9 \%$ FCS.

Figure 1A shows that the CHO-derived cells do not respond to incubation with EGF, which is in accordance with the absence of EGF receptors on these cells (Table 1). Incubation of $\mathrm{CHO} 9$ cells with increasing insulin concentrations evokes an increase in $\left[{ }^{3} \mathrm{H}\right]$ thymidine incorporation with a sigmoidal dose-response relation. The response reaches a maximum at $10^{-7} \mathrm{M}$ insulin, a concentration at which most of the insulin receptors are occupied by insulin (Osterop et al., 1992). In IR800 cells, highly overexpressing the insulin receptor, the level of $\left[{ }^{3} \mathrm{H}\right]$ thymidine incorporation in unstimulated cells has decreased compared to $\mathrm{CHO} 9$ cells, as has been reported previously (Osterop et al., 1992). The dose-response curve has changed to a bell-shaped curve with an optimum at $10^{-9}$ M insulin. $\left[{ }^{3} \mathrm{H}\right]$ Thymidine incorporation is hardly stimulated 

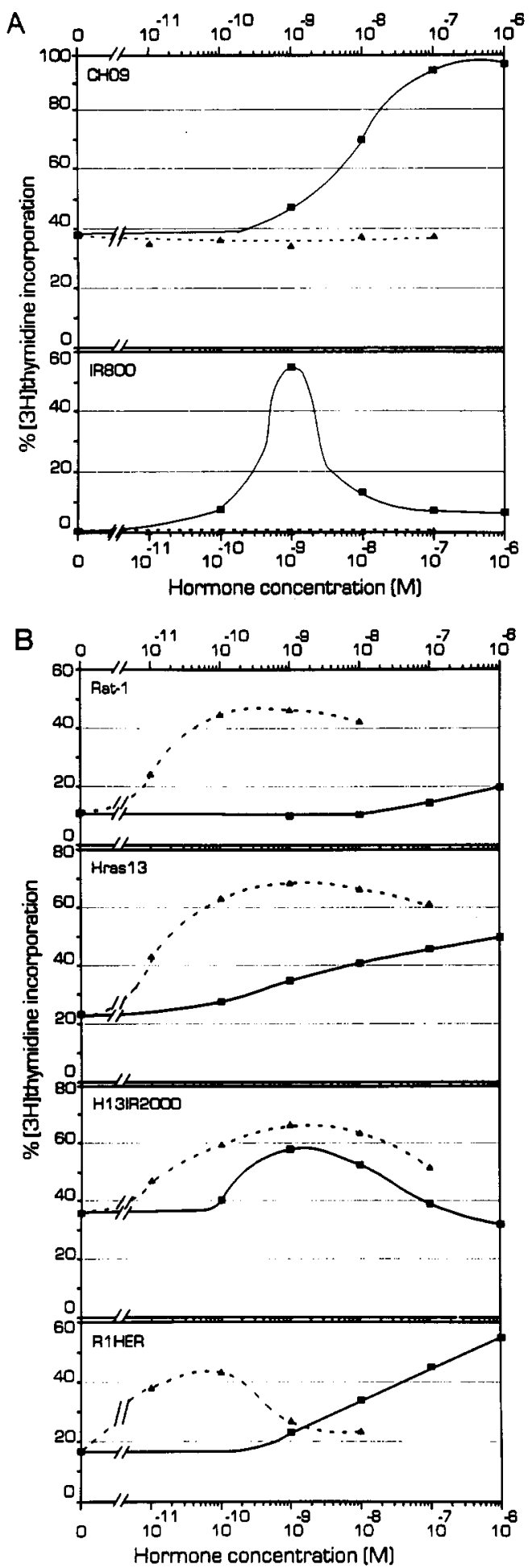

FIGURE 1: Stimulation of $\left[{ }^{3} \mathrm{H}\right]$ thymidine incorporation into DNA in a variety of cells. Incorporation was measured in two panels of cell lines. Panel A shows the results from $\mathrm{CHO} 9$ cells and IR800 cells, a CHO-derived cell line overexpressing insulin receptors; panel B shows results from Rat-1 cells; Hras 13 cells, being Rat-1 cells overexpressing p21 ras; H13IR2000 cells, being Rat-1 cells overexpressing both p21 ras and the insulin receptor; and R1HER cells, being Rat- 1 cells overexpressing the EGF receptor. Cells were serumstarved and subsequently incubated for $16 \mathrm{~h}$ with different concentrations of insulin (- - EGF $(\Delta-\Delta)$, or $9 \%$ FCS. During the last $2 \mathrm{~h}$ of hormone stimulation $\left[{ }^{3} \mathrm{H}\right]$ thymidine was present in the medium. Radioactivity incorporated into the DNA was measured and expressed as percentage of the FCS-stimulated incorporation. The standard deviation is less than $10 \%$ of the mean. Absolute levels of incorporation (in cpm) are for unstimulated and FCS-stimulated cells, respectively: CHO9, 45 000-120 000; IR800, 1000-110 000; Rat-1, 160013 000; Hras 13, 16 000-72 000; H13IR2000, 11 000-31 000; R1HER, $800-5000$. when the IR800 cells are incubated with $10^{-7} \mathrm{M}$ insulin. This phenomenon was observed with different clonal cell lines. The lack of $\left[{ }^{3} \mathrm{H}\right]$ thymidine incorporation, when cells were incubated with high concentrations of insulin, was not due to loss of cells since the total DNA content in the cell lysates did not change markedly throughout the range of hormone concentrations used. Also the amount of $\left[{ }^{3} \mathrm{H}\right]$ thymidine consumed from the cell culture medium showed an inverse relation to the amount of $\left[{ }^{3} \mathrm{H}\right]$ thymidine incorporated into DNA (results not shown). To investigate whether this inhibition of the mitogenic response in IR800 cells, at high insulin concentrations, is a CHO cell line-specific feature, we performed similar experiments with Rat-1-derived cells (Figure 1B).

Compared to $\mathrm{CHO} 9$ cells, the parental Rat-1 cells respond differently toward EGF and insulin. Cells start to incorporate $\left[{ }^{3} \mathrm{H}\right]$ thymidine into their DNA already at low $\left(10^{-11} \mathrm{M}\right)$ EGF concentrations while insulin evokes only a minor response at $10^{-6} \mathrm{M}$. The EGF-dependent dose-response curve reaches a maximum near $10^{-10} \mathrm{M} \mathrm{EGF}$, and at higher concentrations $\left[{ }^{3} \mathrm{H}\right]$ thymidine incorporation slightly decreases. In Hras 13 cells, which overexpress p21 ras, insulin and EGF induce doseresponse curves similar to those of Rat-1 cells. However, the sensitivity for insulin is increased as reported (Burgering et al., 1991). In H13IR2000 cells, overexpressing p21 ras and the insulin receptor, insulin induces a bell-shaped curve like in IR800 cells. The dose-response curve for EGF-induced $\left[{ }^{3} \mathrm{H}\right]$ thymidine incorporation is comparable to those of Rat 1 and Hras 13 cells.

Thus, like in CHO-derived cells, in Rat-1-derived cells the activation of large numbers of insulin receptor suppresses the mitogenic response.

The situation is different in A14 cells which are from a NIH3T3-derived cell line overexpressing insulin receptors. There a normal, sigmoidal relation is seen between insulin and $\left[{ }^{3} \mathrm{H}\right]$ thymidine incorporation (Figure $2 \mathrm{~B}$ ).

Inhibition of $\left[{ }^{3} \mathrm{H}\right]$ thymidine incorporation is also seen for EGF using Rat-1-derived cells (R1HER) which overexpress EGF receptors and expressing endogenous numbers of insulin receptor and p21ras. When these cells are stimulated with insulin, a sigmoidal dose-response relation for $\left[{ }^{3} \mathrm{H}\right]$ thymidine incorporation is obtained, similar to that for Rat-1 cells. The EGF-induced dose-response curve exhibits a bell shape with a maximum at $10^{-11}-10^{-10} \mathrm{M}$ EGF, and at higher EGF concentrations $\left[{ }^{3} \mathrm{H}\right]$ thymidine incorporation declines to basal levels.

Relation between Insulin Receptor Activation, Ras.GTP Formation, and $\left[{ }^{3} \mathrm{H}\right]$ Thymidine Incorporation in IR800 and A14 Cells. Since p21ras is involved in transmitting the mitogenic signal, we determined the relation between insulin receptor activation, Ras.GTP levels, and the mitogenic response in IR800 and A14 cells. Serum-starved cells were labeled with [ ${ }^{32} \mathrm{P}$ ] orthophosphate and stimulated for $5 \mathrm{~min}$ with different concentrations of insulin. P21 ras was isolated from the cell lysates, and Ras-bound GDP and GTP were quantitated. Activation of insulin receptor is reflected by $\beta$-chain autophosphorylation. To determine this, we immunoprecipitated from the same lysates the insulin receptor and measured ${ }^{32} \mathrm{P}$ incorporation in the receptor $\beta$-chain. In Figure $2 A, B$ the percentage Ras.GTP and the radioactivity in the insulin receptor $\beta$-chain are plotted in relation to the insulin concentration. Also the mitogenic response is indicated.

The dose-response relation between insulin concentration and receptor autophosphorylation in IR 800 cells is sigmoidal and reaches a maximum at approximately $10^{-7} \mathrm{M}$ insulin, the $\mathrm{EC}_{50}$ being at $4 \times 10^{-8} \mathrm{M}$ insulin (Figure $2 \mathrm{~A}$ ). It should be noted that this relatively high value is observed when 5 -min 

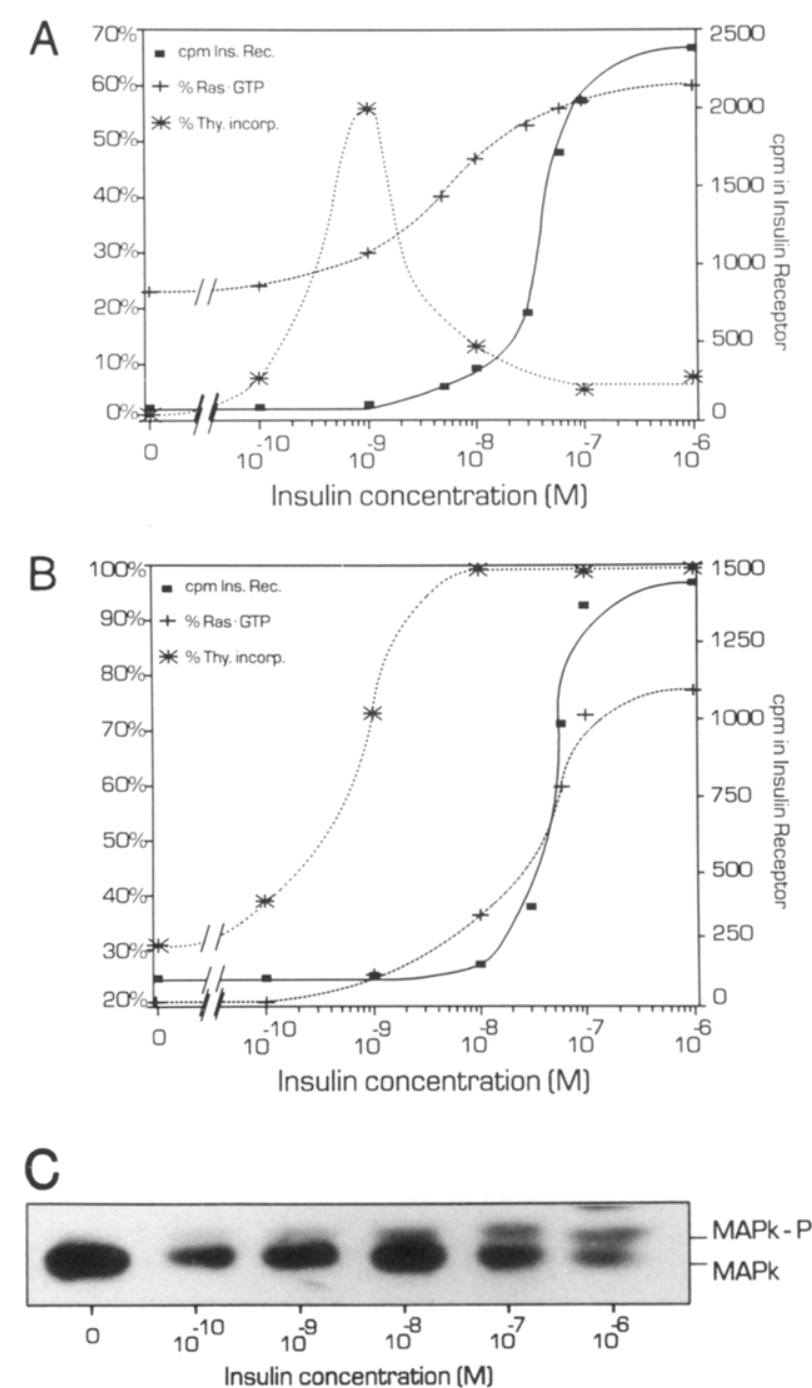

FIGURE 2: Panels A and B: Insulin-stimulated autophosphorylation of insulin receptors, Ras.GTP formation, and mitogenic response in IR800 cells (panel A) and A14 cells (panel B). To detect insulin receptor autophosphorylation and Ras.GTP formation, cells were serum-starved and labeled with $\left[{ }^{32} \mathrm{P}\right]$ orthophosphate, and subsequently, cells were incubated for $5 \mathrm{~min}$ with different concentrations of insulin. Insulin receptors were isolated from cell lysates by immunoprecipitation, and the radioactivity incorporated in the insulin receptor $\beta$-chain was determined (- From the same lysates p21 ras-nucleotide complexes were immunoprecipitated. The radioactivity in GDP and GTP was determined, and the percentage of p21 ras-bound GTP was calculated (+- - ++). The data presented are the means of two independently performed experiments, consisting of at least two replicates/experiment. Standard deviation is less than $10 \%$ of the averaged values. The insulin-induced $\left[{ }^{3} \mathrm{H}\right]$ thymidine incorporation data expressed in percentage of FCS stimulation are obtained as described in Figure $1\left({ }^{*} \ldots *\right)$. Panel C: Insulin-induced MAPkinase phosphorylation in IR800 cells. IR800 cells were incubated for $5 \mathrm{~min}$ with different concentrations of insulin and lysed in SDS sample buffer. Proteins were separated by SDS-PAGE and analyzed by Western blot using anti-MAPkinase antibodies. MAPkinase and phosphorylated MAPkinase are indicated by MAPk and MAPk-P respectively. A similar pattern of MAPkinase activation is seen with A14 cells (not shown).

insulin incubations are used. At longer incubation times, the $\mathrm{EC}_{50}$ shifts to lower insulin concentrations (results not shown). The dose-response curve representing the percentage of Ras.GTP formed is also sigmoidal, with an $\mathrm{EC}_{50}$ at $5 \times 10^{-9}$ $\mathrm{M}$ insulin.

The sigmoidal dose-response curves reflecting both insulin receptor activation and Ras.GTP formation are markedly different from the bell-shaped dose-response curve with IR 800 cells reflecting mitogenicity. So, the decrease of the mitogenic response in IR 800 cells is not caused by a decrease in Ras.GTP

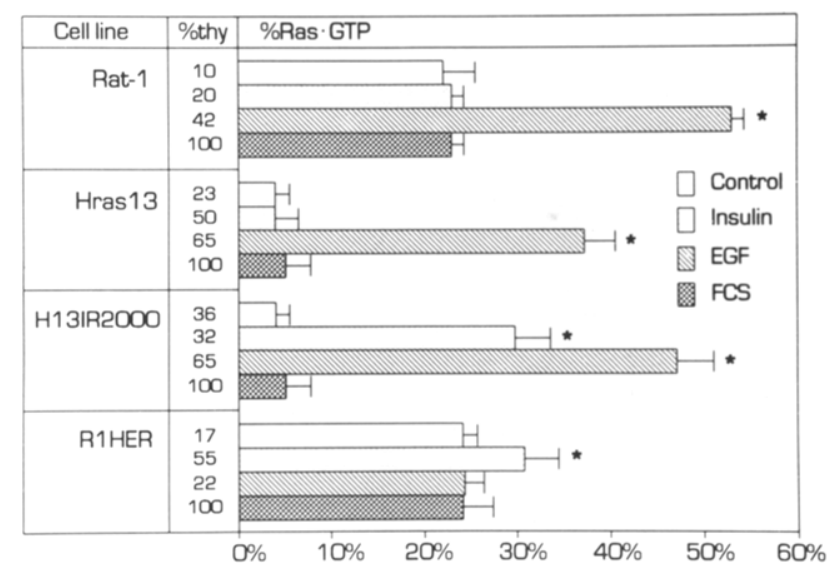

FIGURE 3: Relation between Ras.GTP formation and $\left[{ }^{3} \mathrm{H}\right]$ thymidine incorporation in Rat-1-derived cells. The parental Rat-1 cells, expressing physiological levels of p21 ras and receptors for insulin and EGF; Hras13 cells, expressing elevated levels of p21ras; H13IR2000 cells, overexpressing both p21 ras and the insulin receptor; and R1HER cells, overexpressing only EGF receptors, were used. Hormone-induced Ras.GTP formation was measured. The cells were labeled with $\left.{ }^{32} \mathrm{P}\right]$ orthophosphate and were kept unstimulated as control or were stimulated for $5 \mathrm{~min}$ with $10^{-6} \mathrm{M}$ insulin, $10^{-8} \mathrm{M}$ epidermal growth factor (EGF), or $9 \%$ fetal calf serum (FCS), and p21ras-nucleotide complexes were isolated. The percentage of Ras.GTP was calculated. The values are the mean of at least two experiments, with two replicates/experiment. The corresponding $\left[{ }^{3} \mathrm{H}\right]$ thymidine incorporation values (\% thy) are expressed as percentages of the values obtained with $9 \%$ FCS. indicates significant difference from the control value with $p<0.05$.

levels. Ras.GTP levels even increase at insulin concentrations where the mitogenic response decreases. This same trend is also observed in the cell line H13IR2000, overexpressing both insulin receptors and $\mathrm{p} 21$ ras (results not shown).

A different situation is seen in the A14 cells (Figure 2B). Here, both Ras.GTP formation, receptor autophosphorylation, and the mitogenic response exhibit a sigmoidal dose-response relation.

P21ras is thought to induce the mitogenic response via MAPkinase. We have determined in addition the pattern of insulin-stimulated MAPkinase phosphorylation in IR800 and A14 cells using Western blot analysis. For both cell types a similar pattern of MAPkinase phosphorylation upon increasing the insulin concentration was observed (Figure 2C). In both cell lines MAPkinase phosphorylation resulted in an increased kinase activity when myelic basic protein was used as substrate (results not shown). This observation shows that inhibition of the mitogenic response in IR800 cells at high insulin concentrations does not result from an uncoupling of Ras.GTP to MAPkinase activation.

Ras.GTP Formation and $\left[{ }^{3} \mathrm{H}\right]$ Thymidine Incorporation in Rat-1-Derived Cell Lines. A panel of Rat-1-derived cell lines (Table 1) was stimulated with an excess of insulin $\left(10^{-6} \mathrm{M}\right)$, EGF $\left(10^{-8} \mathrm{M}\right)$, or $9 \% \mathrm{FCS}$. The percentage Ras.GTP formed was determined and plotted together with the percentages of hormone-induced $\left[{ }^{3} \mathrm{H}\right]$ thymidine incorporation (taken from Figure 1). These data are given in Figure 3.

In Rat-1 cells, insulin and FCS do not affect Ras.GTP levels substantially whereas EGF potently stimulates Ras.GTP formation (Osterop et al., 1993). Compared to insulin, EGF increases the mitogenic response more efficient in these cells. In unstimulated Hras13 cells, overexpressing p21ras approximately 100 -fold, the basal percentage of Ras.GTP formed is very low compared to the Rat-1 cells although the absolute number of Ras.GTP molecules per cell is higher. Also in these cells insulin and FCS hardly stimulate Ras.GTP formation. EGF converts $37 \%$ of p 21 ras into the GTP-bound form, representing approximately 1000000 ras molecules. 
Table 2: $\quad$ EGF Receptor-Mediated Inhibition of $\left[{ }^{3} \mathrm{H}\right]$ Thymidine Incorporation ${ }^{\alpha}$

\begin{tabular}{|c|c|c|c|c|c|c|c|c|c|}
\hline \multirow[b]{3}{*}{ cell lines } & \multicolumn{9}{|c|}{$\%$ thymidine incorporation } \\
\hline & \multicolumn{3}{|c|}{ alone } & \multicolumn{3}{|c|}{ plus $10^{-8} \mathrm{M}$ EGF } & \multicolumn{3}{|c|}{ plus $10^{-10} \mathrm{M}$ EGF } \\
\hline & $\overline{C o n}$ & FCS & Ins & Con & FCS & $\overline{\text { Ins }}$ & Con & FCS & Ins \\
\hline $\begin{array}{l}\text { Rat-1 } \\
\text { R1HER }\end{array}$ & $\begin{array}{l}12 \\
17\end{array}$ & $\begin{array}{l}100 \\
100\end{array}$ & $\begin{array}{l}20 \\
50\end{array}$ & $\begin{array}{l}40 \\
20\end{array}$ & $\begin{array}{r}103 \\
35\end{array}$ & $\begin{array}{l}76 \\
19\end{array}$ & $\begin{array}{l}\text { nd } \\
39\end{array}$ & $\begin{array}{r}\text { nd } \\
100\end{array}$ & $\begin{array}{l}\text { nd } \\
45\end{array}$ \\
\hline
\end{tabular}

${ }^{a}$ The stimulation of DNA synthesis in Rat-1 and R1HER cells was measured as described in the legend of Figure 1. Serum-starved cells were kept unstimulated as control (Con) or were stimulated with either $9 \% \mathrm{FCS}$ or $10^{-6} \mathrm{M}$ insulin (Ins) alone or in combination with $10^{-8} \mathrm{M}$ or $10^{-10} \mathrm{M}$ epidermal growth factor (EGF). The radioactivity incorporated is expressed as a percentage of the incorporation with FCS alone and is an average of two experiments, with three replicates/experiment. Standard deviations are less than $5 \%$. nd, not determined.

Thus about 60-fold more Ras.GTP is formed in Hras 13 cells compared to the EGF-stimulated Rat-1 cells. Despite this high number of Ras.GTP molecules, the mitogenic response is only moderately increased when compared to EGFstimulated Rat-1 cells. In the Hras13-derived cell line H13IR2000, overexpressing both p21ras and the insulin receptor, EGF induces similar levels of Ras.GTP and $\left[{ }^{3} \mathrm{H}\right]-$ thymidine incorporation as in Hras 13 cells. One micromolar insulin stimulates the Ras.GTP formation to a high extent in these cells; however, the mitogenic response is hardly activated at this insulin concentration. In R1HER cells, overexpressing only the EGF receptor, insulin stimulates the Ras.GTP formation slightly but induces a marked mitogenic response. EGF stimulation does not induce an increase in the Ras.GTP levels nor in the $\left[{ }^{3} \mathrm{H}\right]$ thymidine incorporation.

Thus, like in CHO-derived cell lines, in Rat-1-derived cell lines the percentage of Ras.GTP is a poor predictor of the increase in DNA synthesis. In fact, both H13IR2000 and R1HER cells, overexpressing receptors for insulin and EGF, respectively, show suppression of the mitogenic response at high ligand levels irrespective of the level of Ras.GTP.

Activation of Overexpressed EGF Receptors Suppresses FCS- and Insulin-Induced $\left[{ }^{3} H\right]$ Thymidine Incorporation. To investigate whether activation of overexpressed receptors interferes with mitogenic stimuli via other receptors, Rat-1 and R1HER cells were used for additional experiments. We stimulated serum-starved cells with either $9 \%$ FCS or $10^{-6} \mathrm{M}$ insulin alone or in combination with $10^{-8} \mathrm{M}$ EGF (high EGF) or $10^{-10} \mathrm{M}$ EGF (low EGF). After $16 \mathrm{~h}\left[{ }^{3} \mathrm{H}\right]$ thymidine incorporation into DNA was quantitated, and the results are given as a percentage of FCS-induced $\left[{ }^{3} \mathrm{H}\right]$ thymidine incorporation (Table 2 ).

In Rat-1 cells insulin alone stimulates the mitogenic response to a low level. Incubation of these cells with high EGF results in $\left[{ }^{3} \mathrm{H}\right]$ thymidine incorporation up to $40 \%$ of the FCS-induced level. The combination of $9 \%$ FCS with high EGF results in a similar level as with FCS alone. The combination of insulin with high EGF acts synergistically.

R1HER cells, overexpressing EGF receptors, show an insulin-induced mitogenic response upto $50 \%$ of the serum level. Incubation of these cells with high EGF alone does not stimulate $\left[{ }^{3} \mathrm{H}\right]$ thymidine incorporation. When high EGF is added in combination with FCS, the serum response is decreased from $100 \%$ to $35 \%$. Addition of high EGF in combination with insulin completely abolishes the insulin response.

When R1HER cells are stimulated with low EGF $\left(10^{-10}\right.$ $\mathrm{M})$, the $\left[{ }^{3} \mathrm{H}\right]$ thymidine incorporation is stimulated. In combination with $9 \%$ FCS, low EGF does not inhibit the serum response nor does it impair the insulin-induced response.

Similar results were obtained with insulin receptor overexpressing cells. For example, in IR 800 cells, the serum response decreases from $100 \%$ to $40 \%$ when $1 \mu \mathrm{M}$ insulin is added together with $9 \%$ FCS, whereas in H13IR2000 cells, expressing besides high numbers of insulin receptor also physiological numbers of EGF receptors, the EGF-induced $\left[{ }^{3} \mathrm{H}\right]$ thymidine incorporation goes down from $60 \%$ to the basal level of $40 \%$ when $1 \mu \mathrm{M}$ insulin is added in combination with EGF.

\section{DISCUSSION}

Stimulation of cells with insulin and EGF induces, as a rapid response, the formation of Ras-GTP. The maximum of this response is within a few minutes after addition of the hormone, after which the signal declines (Osteropet al., 1993). The induced mitogenic response is, at least in part, mediated by Ras.GTP. However, mitogenic stimulation requires the presence of the hormone for many hours. We have examined to what extent the magnitude of the early, transient increase in Ras.GTP predicts the mitogenic response, as reflected by $\left[{ }^{3} \mathrm{H}\right]$ thymidine incorporation. We have previously described that in case of insulin stimulation of cells Ras.GTP levels are strongly increased, when insulin receptor numbers are elevated (Osterop et al., 1992). Therefore, we have included in this study cell lines with physiological and increased receptor numbers. In addition, we have also increased the number of Ras.GTP molecules in the cell by overexpression of p21 ras, and the effect on mitogenic responses was investigated.

Remarkably, we observed that, in cells highly overexpressing receptors for insulin (IR800, H13IR2000 cells) and EGF (R1HER cells), $\left[{ }^{3} \mathrm{H}\right]$ thymidine incorporation is no longer stimulated at hormone levels where most of the receptors are activated. In the case of Her 14 cells, which overexpress EGF receptors, a similar situation has been reported previously (Gill \& Lazar, 1981).

The data show that inhibition of the mitogenic response is not due to the mere presence of overexpressed receptors but rather requires the activation of overexpressed receptors. Moreover, Ras-GTP levels are high in these cells. We observed this phenomenon in the CHO9-derived cell line IR800 and the Rat-1-derived cell line H13IR2000 but not in the NIH3T3derived A14 cell line, where the mitogenicity is not inhibited, which indicates cell type-specific variation. In both in IR800 cells and A14 cells dose-response curves for MAPkinase activation by insulin are similar; this observation indicates that the inhibition of mitogenicity at high insulin levels in IR800 cells is not simply due to an uncoupling of activated p21 ras with the MAPkinase pathway like the one which occurs by high cAMP (Burgering et al., 1993; Cook et al., 1993).

Receptor activation results in autophosphorylation on tyrosine, and these phosphotyrosine residues are docking places for proteins with SH2 domains (Anderson et al., 1990; Bardelli et al., 1992; Carpenter, 1992). The $K_{\mathrm{D}}$ of the resulting complex depends on the specific sequence of the SH2 domain and on the specific sequence flanking the phosphotyrosine residue (Hidaka et al., 1991; Songyang et al., 1993). Under physiological conditions, activation of a few thousand tyrosine kinase receptors is sufficient for a maximal response. Given this low number, only high-affinity complexes are expected 
to be formed between activated receptors and proteins with matching SH2 domains. In the receptor-overexpressing cell lines, receptor numbers are increased several hundredfold over the physiological number, and as a result, a promiscuous interaction may occur with SH2 domains of proteins normally not selected. Such an interaction may result in a competition with existing, low-abundance high-affinity, phosphotyrosine$\mathrm{SH} 2$ domain complexes, thus disrupting physiological protein networks (Backer et al., 1993; Rotin et al., 1992; Shen et al., 1991; Wood et al., 1992). Since Ras.GTP formation is not abrogated, the interference does not occur in the signaling pathway leading to Ras.GTP formation but rather downstream from p21ras or in a pathway synergizing with Ras.GTP. A similar situation of promiscuous interactions between phosphotyrosine proteins and SH2 domains seems to occur when IRS-1 is overexpressed. This protein is an essential signaling intermediate of the insulin receptor and becomes phosphorylated on multiple tyrosine residues after activation of the insulin receptor. Overexpression of IRS-1 also interferes with the mitogenic response of insulin (Sun et al., 1992).

The mechanism by which p2lras signals downstream proceeds at least in part via the p21ras-Raf-MAPkinase pathway (Moodie et al., 1993; Vojtek et al., 1993; Zhang et al., 1993; Warne et al., 1993). This particular route is not affected by activation of overexpressed insulin receptors. A number of studies have also suggested that p120-GAP may act as an effector (Medema et al., 1992; Duchesne et al., 1993). The protein structure of p120-GAP exhibits two SH2 domains, and it has the ability to interact with tyrosinephosphorylated receptors, like the receptors for insulin, EGF, and PDGF (Ruggieri \& McCormick, 1992; Margolis et al., 1992; Kashishian et al., 1992). Thus the effector function of p120-GAP may be negatively affected by the presence of overexpressed, activated receptors. Results by Valius and Kazlauskas (1993), using mutant PDGF receptors, show that the mitogenic potency of wild-type PDGF receptors, which bind p120-GAP, is lower than that of a mutant PDGF receptor which is unable to interact with p120-GAP. This observation suggests that unbound p120-GAP contributes to mitogenic signaling and that activation of overexpressed EGF- and insulin receptors may trap most of the p120-GAP.

Also the $\mathrm{SH} 2$ domain containing protein $\mathrm{p} 91$, or related proteins, may contribute to mitogenic signaling (Montminy, 1993). These recently characterized proteins undergo tyrosine phosphorylation by certain tyrosine kinase receptors and shuttle subsequently to the nucleus where they regulate gene expression via sis-inducible elements. Also these shuttle proteins may be trapped by overexpressed and activated insulin receptors.

Another possibility to explain a loss of mitogenic response at high receptor numbers and ligand concentrations could be that under these conditions all the receptors become downregulated, thereby generating a situation without receptors and thus without mitogenic response. We have shown previously that, in the case of H13IR2000 cells, high insulin concentrations downregulate only a small fraction of the insulin receptor population, making this situation unlikely (Osterop et al., 1993).

Our results show that the early increase of Ras-GTP levels does not correlate with the magnitude of the mitogenic response. To induce progression from the $\mathrm{Gl}$ phase to the $\mathrm{S}$ phase in the cell cycle, progression factors, like EGF and insulin, must be present permanently for many hours (Stiles, 1983).

This observation implies that the transient increase in Ras.GTP, which has occurred during the short incubation period (Osterop et al., 1993; Qiu \& Green, 1991), is not sufficient by itself for $G 1$ to $S$ progression. The presence of active p21ras seems also required during later phases in the G1 period because microinjection of p21ras-inactivating antibodies during the late part of the $\mathrm{Gl}$ phase still inhibits serum-induced $\mathrm{G} 1$ to S progression of NIH3T3 cells (Mulcahy et al., 1985). These observations are in line with our observed lack of correlation between the magnitude of the early and transient increase in Ras.GTP and the long-term stimulation of $\left[{ }^{3} \mathrm{H}\right]$ thymidine incorporation.

\section{ACKNOWLEDGMENT}

We thank Dr. J. L. Bos for many helpful discussions and critical reading of the manuscript.

\section{REFERENCES}

Anderson, D., Koch, C. A., Grey, L., Ellis, C., Moran, M. F., \& Pawson, T. (1990) Science 250, 979-982.

Backer, J. M., Myers, M. G., Sun, X. J., Chin, D. J., Shoelson, S. E., Miralpeix, M., \& White, M. F. (1993) J. Biol. Chem. 268, 8204-8212.

Barbacid, M. (1987) Annu. Rev. Biochem. 56, 779-827.

Bardelli, A., Maina, F., Gout, I., Fry, M. J., Waterfield, M. D., Comoglio, P. M., \& Ponzetto, C. (1992) Oncogene 7, 19731978.

Buday, L., \& Downward, J. (1993) Mol. Cell. Biol. 13, 19031910.

Burgering, B. M. Th., Medema, R. H., Maassen, J. A., Van de Wetering, M. L., Van der Eb, A. J., McCormick, F., \& Bos, J. L. (1991) EMBO J. 10, 1103-1109.

Burgering, B. M. Th., Pronk, G. J., Van Weeren, P. C., Chardin, P., \& Bos, J. L. (1993) EMBO J. 12, 4211-4220.

Cai, H., Szeberényi, J., \& Cooper, G. M. (1990) Mol. Cell. Biol. 10, 5314-5323.

Carpenter, G. (1992) FASEB J. 6, 3283-3289.

Cook, S. J., \& McCormick, F. (1993) Science 262, 1069-1072.

Downward, J., de Gunzburg, J., Riehl, R., \& Weinberg, R. A. (1988) Proc. Natl. Acad. Sci. U.S.A. 85, 5774-5778.

Downward, J., Graves, J. D., Warne, P. H., Rayter, S., \& Cantrell, D. A. (1990a) Nature 346, 719-723.

Downward, J., Riehl, R., Wu, L., \& Weinberg, R. A. (1990b) Proc. Natl. Acad. Sci. U.S.A. 87, 5998-6002.

Duchesne, M., Schweighoffer, F., Parker, F., Clerc, F., Frobert, Y., Thang, M. N., \& Tocque, B. (1993) Science 259, 525-528. Egan, S. E., Giddings, B. W., Brooks, M. W., Buday, L., Sizeland, A. M., \& Weinberg, R. A. (1993) Nature 363, 45-51.

Feramisco, J. R., Gross, M., Kamata, T., Rosenberg, M., \& Sweet, R. W. (1984) Cell 38, 109-117.

Gill, G. N., \& Lazar, C. S. (1981) Nature 293, 305-307.

Grand, R. J. A., \& Owen, D. (1991) Biochem. J. 279, 609-631.

Graves, J. D., Downward, J., Izquierdo-Pastor, M., Rayter, S., Warne, P. H., \& Cantrell, D. A. (1992) J. Immunol. 148, 2417-2422.

Hidaka, M., Homma, Y., \& Takenawa, T. (1991) Biochem. Biophys. Res. Commun. 180, 1490-1497.

Izquierdo, M., Downward, J., Otani, H., Leonard, W. J., \& Cantrell, D. A. (1992) Eur. J. Immunol. 22, 817-821.

Kashishian, A., Kazlauskas, A., \& Cooper, J. A. (1992) EMBO J. 11, 1373-1382.

Kung, H.-F., Smith, M. R., Bekesi, E., Manne, V., \& Stacey, D. W. (1986) Exp. Cell Res. 162, 363-371.

Margolis, B., Silvennoinen, O., Comoglio, F., Roonprapunt, C., Skolnik, E., Ullrich, A., \& Schlessinger, J. (1992) Proc. Natl. Acad. Sci. U.S.A. 89, 8894-8898.

McCormick, F. (1992) Philos. Trans. R. Soc. London B 336, 43-48.

McCormick, F. (1993) Nature 363, 15-16.

Medema, R. H., Wubbolts, R., \& Bos, J. L. (1991) Mol. Cell. Biol. 11, 5963-5967.

Medema, R. H., De Laat, W. L., Martin, G. A., McCormick, F., \& Bos, J. L. (1992) Mol. Cell. Biol. 12, 3425-3430. 
Montminy, M. (1993) Science 261, 1694-1695.

Moodie, S. A., Willumsen, B. M., Weber, M. J., \& Wolfman, A. (1993) Science 260, 1658-1661.

Moran, M. F., Polakis, P., McCormick, F., Pawson, T., \& Ellis, C. (1991) Mol. Cell. Biol. 11, 1804-1812.

Mulcahy, L. S., Smith, M. R., \& Stacey, D. W. (1985) Nature $313,241-243$.

Nakafuku, M., Satoh, T., \& Kaziro, Y. (1992) J. Biol. Chem. 267, 19448-19454.

Osterop, A. P. R. M., Medema, R. H., Bos, J. L., Van der Zon, G. C. M., Moller, D. E., Flier, J. S., Möller, W., \& Maassen, J. A. (1992) J. Biol. Chem. 267, 14647-14653.

Osterop, A. P. R. M., Medema, R. H., Van der Zon, G. C. M., Bos, J. L., Möller, W., \& Maassen, J. A. (1993) Eur. J. Biochem. 212, 477-482.

Qiu, M.-S., \& Green, S. H. (1991) Neuron 7, 937-946.

Randazzo, P. A., Northup, J. K., \& Kahn, R. A. (1992) J. Biol. Chem. 267, 18182-18189.

Rotin, D., Honegger, A. M., Margolis, B. L., Ullrich, A., \& Schlessinger, J. (1992) J. Biol. Chem. 267, 9678-9683.

Ruggieri, R., \& McCormick, F. (1992) Nature 353, 390-391.

Satoh, T., Endo, M., Nakafuku, M., Akiyama, T., Yamamoto, T., \& Kaziro, Y. (1990a) Proc. Natl. Acad. Sci. U.S.A. 87, 7926-7929.

Satoh, T., Endo, M., Nakafuku, M., Nakamura, S., \& Kaziro, Y. (1990b) Proc. Natl. Acad. Sci. U.S.A. 87, 5993-5997.

Shen, S.-H., Bastien, L., Posner, B. I., \& Chretien, P. (1991) Nature 352, 736-739.

Skolnik, E. Y., Lee, C.-H., Batzer, A., Vicentini, L. M., Zhou, M., Daly, R., Myers, M. J., Jr., Backer, J. M., Ullrich, A., White, M. F., \& Schlessinger, J. (1993) EMBO J. 12, 19291936.
Smith, M. R., DeGudicibus, S. J., \& Stacey, D. W. (1986) Nature $320,540-543$.

Songyang, Z., Shoelson, S. E., Chaudhuri, M., Gish, G., Pawson, T., Haser, W. G., King, F., Roberts, T., Ratnofsky, S., Lechleider, R. J., Neel, B. G., Birge, R. B., Fajardo, J. E., Chou, M. M., Hanafusa, H., Schaffhausen, B., \& Cantley, L. C. (1993) Cell 72, 767-778.

Stacey, D. W., \& Kung, H.-F. (1984) Nature 310, 508-511.

Stiles, C. D. (1983) Cell 33, 653-655.

Sun, X. J., Miralpeix, M., Myers, M. G., Glasheen, E. M., Backer, J. M., Kahn, C. R., \& White, M. F. (1992) J. Biol. Chem. 267, 22662-22672.

Szeberényi, J., Erhardt, P., Cai, H., \& Cooper, G. M. (1992) Oncogene 7, 2105-2113.

Valius, M., \& Kazlauskas, A. (1993) Cell 73, 321-334.

Veda, T., Takeyama, Y., Ohmori, T., Ohyanagi, H., Saitoh, Y., \& Takai, Y. (1991) Biochemistry 30, 909-917.

Vojtek, A. B., Hollenberg, S. M., \& Cooper, J. A. (1993) Cell 74, 205-214.

Warne, P. H., Viciana, P. R., \& Downward, J. (1993) Nature 364, 352-355.

West, M., Kung, H.-F., \& Kamata, T. (1990) FEBS Lett. 259, 245-248.

Wolfman, A., \& Macara, I. G. (1990) Science 248, 67-69.

Wood, E. R., McDonald, O. B., \& Sahyoun, N. (1992) J. Biol. Chem. 267, 14138-14144.

Zhang, X.-F., Settleman, J., Kyriakis, J. M., Takeuchi-Suzuki, E., Elledge, S. J., Marshall, M. S., Bruder, J. T., Rapp, U. R., \& Avruch, J. (1993) Nature 364, 308-313. 